University of Nebraska - Lincoln

DigitalCommons@University of Nebraska - Lincoln

Faculty Publications: Department of

Entomology

Entomology, Department of

2012

\title{
Susceptibility of Cry1Ab Maize-Resistant and -Susceptible Strains of Sugarcane Borer (Lepidoptera: Crambidae) to Four Individual Cry Proteins
}

\author{
Liping Zhang \\ Louisiana State University Agricultural Center and Shanxi Academy of Agricultural Sciences \\ Fangneng Huang \\ Louisiana State University Agricultural Center, fhuang@agcenter.Isu.edu \\ B. Rogers Leonard \\ Louisiana State University Agricultural Center, rleonard@agcenter.Isu.edu \\ Mao Chen \\ Monsanto \\ Thomas Clark \\ Monsanto
}

See next page for additional authors

Follow this and additional works at: https://digitalcommons.unl.edu/entomologyfacpub

Part of the Agricultural Science Commons, Agriculture Commons, and the Entomology Commons

Zhang, Liping; Huang, Fangneng; Leonard, B. Rogers; Chen, Mao; Clark, Thomas; Zhu, Yu Cheng; Wangila, David S.; Yang, Fei; and Niu, Ying, "Susceptibility of Cry1Ab Maize-Resistant and -Susceptible Strains of Sugarcane Borer (Lepidoptera: Crambidae) to Four Individual Cry Proteins" (2012). Faculty Publications: Department of Entomology. 595.

https://digitalcommons.unl.edu/entomologyfacpub/595

This Article is brought to you for free and open access by the Entomology, Department of at DigitalCommons@University of Nebraska - Lincoln. It has been accepted for inclusion in Faculty Publications: Department of Entomology by an authorized administrator of DigitalCommons@University of Nebraska - Lincoln. 


\section{Authors}

Liping Zhang, Fangneng Huang, B. Rogers Leonard, Mao Chen, Thomas Clark, Yu Cheng Zhu, David S. Wangila, Fei Yang, and Ying Niu 


\title{
Susceptibility of Cry1 Ab maize-resistant and -susceptible strains of sugarcane borer (Lepidoptera: Crambidae) to four individual Cry proteins ${ }^{\text {is }}$
}

\author{
Liping Zhang a,b, Fangneng Huang a,*, B. Rogers Leonard ${ }^{\mathrm{a}}$, Mao Chen ${ }^{\mathrm{c}}$, Thomas Clark ${ }^{\mathrm{c}}$, Yu Cheng Zhu ${ }^{\mathrm{d}}$, \\ David S. Wangila ${ }^{a}$, Fei Yang ${ }^{a}$, Ying Niu ${ }^{a}$ \\ a Department of Entomology, Louisiana State University Agricultural Center, Baton Rouge, LA 70803, USA \\ ${ }^{\mathrm{b}}$ Cotton Research Institute, Shanxi Academy of Agricultural Sciences, Yuncheng, Shanxi, China \\ ' Monsanto Company, Chesterfield, MO 63017, USA \\ d Jamie Whitten Delta States Research Center, USDA-ARS, Stoneville, MS 38776, USA
}

\section{A R T I C L E I N F O}

\section{Article history:}

Received 29 August 2012

Accepted 15 December 2012

Available online 24 December 2012

\section{Keywords:}

Diatraea saccharalis

Bacillus thuringiensis

Cross-resistance

Resistance management

Bt maize

\begin{abstract}
A B S T R A C T
Sugarcane borer, Diatraea saccharalis (F.), is a major target of Bt maize in South America and many areas of the US mid-south region. Six laboratory strains of $D$. saccharalis were established from six single-pair $F_{2}$ families possessing major resistance alleles to Cry1 Ab maize hybrids. Susceptibility of the six strains was evaluated on diet treated with each of four purified trypsin-activated Bt proteins, Cry1 Ab, Cry1 Aa, Cry1Ac and Cry1F. Bt susceptibility of the six strains was compared with that of known Cry1Ab-susceptible and -resistant strains of $D$. saccharalis. At least two of the six strains demonstrated a similar level (>526-fold) of resistance to Cry1 Ab as shown in the known Cry1Ab-resistant strain, while resistance levels were relatively lower for other strains (116- to 129 -fold). All the six strains were highly cross-resistant to Cry1Aa (71- to 292-fold) and Cry1 Ac (30- to 248 -fold), but only with a low level to Cry1F ( $<7$-fold). Larval growth of all six strains was also inhibited on Bt-treated diet, but, except for Cry1F, the growth inhibition of the six strains was considerably less than that of the Cry $1 \mathrm{Ab}$-susceptible larvae. The results provide clear evidence that the observed resistance to Cry1 Ab maize in the six strains is a result of resistance to the Cry $1 \mathrm{Ab}$ protein in the plants. The low level of cross-resistance between Cry $1 \mathrm{~A}$ and Cry $1 \mathrm{~F}$ suggests that pyramiding these two types of Bt proteins into a plant could be a good strategy for managing $D$. saccharalis. (C) 2012 Elsevier Inc. All rights reserved.
\end{abstract}

\section{Introduction}

Transgenic insect-resistant crops expressing Bacillus thuringiensis (Bt) proteins have been used successfully for insect management worldwide since they were first commercialized in 1996 (Cattaneo et al., 2006; Wu et al., 2008; Hutchison et al., 2010; James, 2011). However, as Bt maize provides unprecedented control of some caterpillar pests through a simple seed choice, the widespread use of Bt crops could also accelerate development of resistance in target pest populations. Up to date, field resistance that leads to control failure or significantly reduced control efficacy due to intensive use of Bt crops has been documented in at least four cases: fall armyworm Spodoptera frugiperda JE Smith to Cry1F maize in Puerto Rico (Storer et al., 2010), African stem borer Busseola fusca Fuller, to Cry1Ab maize in South Africa (Van Rensburg, 2007), pink bollworm, Pectinophora gossypiella (Saunders), to Bt

\footnotetext{
This paper reports research results only. Mention of a proprietary product name does not constitute an endorsement for its use by Louisiana State University Agricultural Center.

* Corresponding author. Fax: +1 02255781643.

E-mail address: fhuang@agcenter.lsu.edu (F. Huang).
}

cotton in India (Dhurua and Gujar, 2011), and western corn rootworm, Diabrotica virgifera virgifera LeConte, to Cry3Bb1 maize in the United States (Gassmann et al., 2011).

The sugarcane borer, Diatraea saccharalis (F.), is a major maize borer pest in many areas of the mid-southern region of the United States and South America (PRNewswire, 2009; Huang et al., 2012a). Studies have shown that $D$. saccharalis is inherently less susceptible to Bt proteins than other major maize borer species such as European corn borer, Ostrinia nubilalis (Hübner), and southwestern corn borer, Diatraea grandiosella Dyar (Huang et al., 2006). Both Wu et al. (2007) and Ghimire et al. (2011) also reported that most commercial Cry1Ab maize hybrids did not express a "high dose" of Bt proteins for $D$. saccharalis. To ensure the long-term success of Bt maize for managing stalk borers in the mid-southern region, since 2004, a cost-effective Bt resistance monitoring program has been implemented in the region (Huang et al., 2012a). By using an $F_{2} / F_{1}$ screen, the monitoring program can detect rare resistance alleles to Cry $1 \mathrm{Ab}$ maize in field populations of $D$. saccharalis. In 2009, a total of $110 \mathrm{~F}_{2}$ families of $D$. saccharalis derived from 191 feral individuals sampled from maize fields in southeast Louisiana were examined for resistance to Cry1 $\mathrm{Ab}$ maize using an $\mathrm{F}_{2}$ screen (Huang et al., 2012a). Eight out of the 191 individuals were identified to possess 
major resistance alleles to Cry $1 \mathrm{Ab}$ maize plants. Larvae of these families were able to survive on whole plants of commercial Cry $1 \mathrm{Ab}$ maize hybrids in the greenhouse (Huang et al., 2012a). Laboratory strains were established for six of the eight families.

Information on cross-resistance of an insect pest to insecticides is essential for understanding mechanisms of resistance and developing resistance management strategies. Cross-resistance is common among Bt toxins (Tabashnik et al., 1994, 2000; Zhao et al., 2001; Siqueria et al., 2004; Li et al., 2005; Ali and Luttrell, 2007; Wu et al., 2009; Crespo et al., 2011), but several studies also showed that no or low level of cross-resistance can exist among Bt proteins in some cases. For example, a Cry1 Ab resistant strain of $O$. nubilalis was not resistant to Cry9C and had only a very low level of cross-resistance to Cry1F (Siqueria et al., 2004). Similarly, Cry $2 \mathrm{Ab}$ resistant strains of cotton bollworm, Helicoverpa armigera (Hübner), were found to be susceptible to purified Cry1Ac protein as well as Cry1Ac cotton plants (Mahon et al., 2007; Downes et al., 2010). In D. saccharalis, Wu et al. (2009) reported that a Cry1Abresistant strain also exhibited a high level of cross-resistance to Cry1Aa and Cry1Ac but just exhibited a very low level of crossresistance to Cry1A.105 and no cross-resistance to Cry2Ab2. The objective of this study is to characterize the susceptibility of the six Cry1 Ab-maize resistant strains of $D$. saccharalis that were established in 2009 to four Cry proteins commonly used in Bt crops and thus to generate essential information needed for further studies.

\section{Materials and methods}

\subsection{Sources of Cry1Ab-susceptible and -resistant strains of D. saccharalis}

A Cry1Ab-susceptible strain (Cry1Ab-SS) of D. saccharalis was established using larvae collected from maize fields near Winnsboro in Northeast Louisiana in 2009. The Cry1 Ab-SS strain is susceptible to purified Cry1Aa, Cry1Ab, and Cry1Ac (Huang et al., 2012b), as well as to Bt maize plants expressing Cry1 Ab, Cry1A.105, Cry2Ab2, and/or Cry1F (Wangila et al., 2012). Six Cry1Ab-maize resistant strains of $D$. saccharalis were developed from six out of the eight single-pair families that were identified to possess major resistance alleles to Cry1 Ab maize in 2009 (Huang et al., 2012a). These eight single-pair families were selected using an $F_{2}$ screen from 191 feral individuals sampled from maize field in southeast Louisiana in 2009 in the same location as the Cry1Ab-SS strain was collected. These families have demonstrated survival on $\mathrm{Cry} 1 \mathrm{Ab}$ maize plants in the greenhouse and thus are considered to carry major resistance alleles to Cry1 Ab maize plants (Huang et al., 2012a). The six Cry1 $\mathrm{Ab}$ maize resistant strains were labeled: SCB-RR-43A, SCB-RR-L5B, SCB-RR-L6, SCB-RR-41, SCB-RR-46, and SCB-RR-54, respectively. In addition, a known Cry1Ab-resistant strain (Cry1Ab-RR-2004) of D. saccharalis was also included in the bioassays in this study to serve as a positive control. Cry1Ab-RR2004 was established from a field collection in 2004, which has been well documented to be highly resistant to both Cry1 Ab-maize plants and purified Cry $1 \mathrm{Ab}$ protein (Huang et al., 2007a, 2007b; Wu et al., 2007; Ghimire et al., 2011; Wangila et al., 2012). Individuals of the seven resistant strains were backcrossed 2-3 times with individuals from the Cry1 Ab-SS strain and re-selected for Bt resistance using leaf tissue from Cry1 Ab expressing maize plants during the $\mathrm{F}_{2}$ generations of the backcross. The backcrossed and re-selected resistant strains were used in the current bioassays.

\subsection{Sources of Cry proteins}

Susceptibility of Cry1Ab-SS and the seven Bt resistant strains of D. saccharalis was assayed with four individual Cry proteins: Cry1 Aa, Cry1Ab, Cry1Ac, and Cry1F. Purified (99.9\%) trypsin-activated Cry proteins were obtained from Case Western Reserve University Cleveland, Ohio, USA. The activated Cry proteins were lyophilized before they were used in the bioassays. The purity of these four proteins was determined using high-performance liquid chromatography and sodium dodecyl sulfate polyacrylamide gel electrophoresis (Pusztai-Carey et al., 1995; Masson et al., 1998).

\subsection{Insect bioassay}

Larval susceptibility of the eight strains of $D$. saccharalis to four Cry proteins was determined using a standard diet incorporation method as described in Wu et al. (2009). Each individual Cry protein was incorporated into a meridic diet prepared for rearing $D$. saccharalis (Bio-Serv, Frenchtown, NJ). Each bioassay included 6Cry protein concentrations plus one untreated control. The range of Cry protein concentrations varied slightly based on preliminary bioassays. In most cases, Cry protein concentrations used in each bioassay ranged from 0.0316 to $31.6 \mu \mathrm{g} / \mathrm{g}$ or 0.0316 to $100 \mu \mathrm{g} / \mathrm{g}$. There were two bioassays for testing SCB-RR-L5B with each of Cry1Aa and Cry1Ab, whereas one bioassay was conducted for all other combinations of Cry protein and insect strain. For diet incorporation, individual Cry proteins were first suspended and diluted in distilled water. The desired Cry protein concentrations were achieved by mixing appropriate volumes of Cry protein solution into the diet just prior to dispensing the diet into individual cells of 128-cell trays (Bio-Ba-128, C-D International, Pitman, NJ). Diet mixed with distilled water was used as a control in each bioassay. In the bioassay, approximately $0.7 \mathrm{ml}$ of treated diet was poured into each cell using 10 or $20-\mathrm{ml}$ syringes (Becton, Dickinson and Company, Franklin Lakes, NJ). One neonate ( $<24$-h old) was placed on the diet surface of each cell. Each combination of insect strain by Cry protein concentration was replicated 4 times with 16-32 larvae in each replication. The bioassay trays were held in an environmental chamber maintained at $28{ }^{\circ} \mathrm{C}, 50 \% \mathrm{RH}$, and a photoperiod of $16: 8$ (L:D) h. Larval mortality, larval weight, and the number of surviving larvae that did not gain significant weight $(<0.1 \mathrm{mg}$ per larva and still in first instar) were recorded on the 7 th day after inoculation.

\subsection{Data analysis}

Larval mortality was measured as 'practical' mortality as described in Huang et al. (2007b) and calculated using the equation: mortality $(\%)=100 \times($ number of dead larvae + number of surviving larvae that had a body weight of $\leqslant 0.1 \mathrm{mg}$ per larva)/total number of insects assayed. The mortality of each insect strain at a Cry protein concentration was corrected for larval mortality on the control diet using the method described by Abbott (1925). Corrected dose/mortality data were subjected to probit analysis (Finney, 1971; SAS Institute Inc, 2010) for determining Cry concentrations that produced a $50 \%$ mortality value $\left(\mathrm{LC}_{50}\right)$ and the corresponding 95\% confidence limit (CL). The treatments used in the probit analysis in a bioassay included the highest concentration that produced zero mortality, the lowest concentration that resulted in $100 \%$ mortality, and all results between those extremes. Data for those cases that contained two bioassays were pooled in the probit analysis. Resistance ratios for each Cry protein were calculated using the $\mathrm{LC}_{50}$ value of a resistant strain divided by the $\mathrm{LC}_{50}$ of the Cry1 Ab-SS strain. In some cases, the $\mathrm{LC}_{50}$ value of an insect strain was considered to be greater than the highest Cry concentration used in the bioassay if its larval mortality was $<50 \%$ at the highest concentration.

In addition, percentage of larval growth inhibition of $D$. saccharalis on a Cry protein-treated diet was calculated using the formula: larval growth inhibition $(\%)=100 \times$ (body weight of larvae feeding on control diet - body weight of larvae feeding on Bt diet)/(body 
weight of larvae feeding on control diet $-0.1 \mathrm{mg}$ ) (Huang et al., 2012b). Growth inhibition data were first analyzed using a twoway analysis of variance (ANOVA) with insect strain and Cry concentration as the two main factors to determine the effect of main factor and interaction (SAS Institute Inc, 2010). Because there were so many combinations of insect strain and Cry concentration, growth inhibition data of the eight insect strains were then analyzed using one-way ANOVA for each Cry protein concentration. Comparison among insect strains at a specific Cry concentration was determined using the least square difference test at $\alpha=0.05$ level (SAS Institute Inc, 2010). Based on the available data, comparisons among the eight insect strains were made in the range of Cry protein concentration from 0.1 to $31.6 \mu \mathrm{g} / \mathrm{g}$ for Cry $1 \mathrm{Aa}$, Cry $1 \mathrm{Ab}$ and Cry $1 \mathrm{Ac}$ and from 0.0316 to $10 \mu \mathrm{g} / \mathrm{g}$ for Cry1F.

\section{Results}

\subsection{Median lethal concentration, $L C_{50}$}

The $\mathrm{LC}_{50}$ value of the Cry1Ab-SS strain of $D$. saccharalis on Cry $1 \mathrm{Ab}$ diet was $0.19 \mu \mathrm{g} / \mathrm{g}$ with a $95 \% \mathrm{CL}$ of $0.16-0.22 \mu \mathrm{g} / \mathrm{g}$ (Table 1$)$. Compared to the Cry $1 \mathrm{Ab}$ susceptible strain, the Cry $1 \mathrm{Ab}-$ RR-2004 and all other six strains that were identified to possess resistance alleles to Cry $1 \mathrm{Ab}$ maize in 2009 were considerably less susceptible to Cry1 Ab, Cry1Aa, and Cry1Ac (Table 1 ). The $\mathrm{LC}_{50}$ values of Cry1Ab-RR-2004, SCB-RR-43A, SCB-RR-L5B, and SCB-RR-54 couldn't be determined for Cry1Ab with the probit analysis because the highest concentrations used in the bioassays resulted in $<50 \%$ mortality. Thus, resistance ratios to Cry $1 \mathrm{Ab}$ based on the highest $\mathrm{Bt}$ concentrations used in the bioassays for the four strains were $>53$-fold for SCB-RR-54 and $>526$-fold for Cry1Ab-RR-2004, SCB-RR-43A, and SCB-RR-L5B. The $\mathrm{LC}_{50}$ values of Cry1Ab for the three other resistant strains were similar, ranged from $22.1 \mu \mathrm{g} / \mathrm{g}$ for SCB-RR-46 to $24.6 \mu \mathrm{g} / \mathrm{g}$ for SCB-RR-L6, which were 116 - to 129 -fold greater than the $\mathrm{LC}_{50}$ of the susceptible strain. The differences in $\mathrm{LC}_{50}$ values of Cry1 $\mathrm{Ab}$ between the resistant and Cry1 $\mathrm{Ab}$ SS strains were significant based on the non-overlapping of the $95 \%$ confidence limits for all the three resistant strains (Table 1 ).

Compared to Cry1 Ab protein, Cry1Aa appeared to be more toxic to $D$. saccharalis. The calculated $\mathrm{LC}_{50}$ value of Cry1Aa based on larval mortality of Cry1 Ab-SS was $0.04 \mu \mathrm{g} / \mathrm{g}$ with a $95 \% \mathrm{CL}$ of $0.03-$ $0.05 \mu \mathrm{g} / \mathrm{g}$ (Table 1 ). The $\mathrm{LC}_{50}$ values of the seven resistant strains ranged from $2.84 \mu \mathrm{g} / \mathrm{g}$ (71-fold) for SCB-RR-54 to $11.7 \mu \mathrm{g} / \mathrm{g}$ (292fold) for SCB-RR-43A, which were significantly greater than that of Cry $1 \mathrm{Ab}-\mathrm{SS}$ based on the non-overlapping of the $95 \%$ confidence limits. Differences in $\mathrm{LC}_{50}$ values of Cry1Aa were also observed among the seven resistant strains. The $\mathrm{LC}_{50}$ value of Cry1Aa for SCB-RR-43A was greater than that of SCB-RR-41 (3.05 $\mu \mathrm{g} / \mathrm{g})$, SCBRR-46 $\quad(3.76 \mu \mathrm{g} / \mathrm{g}), \quad$ SCB-RR-L5B $(4.11 \mu \mathrm{g} / \mathrm{g})$, and SCB-RR-L6 $(6.33 \mu \mathrm{g} / \mathrm{g})$ based on the non-overlapping of the $95 \%$ confidence limits.

The seven Bt resistant strains of $D$. saccharalis were also highly resistant to Cry1Ac protein. The calculated $\mathrm{LC}_{50}$ value of Cry1 Ac for

Table 1

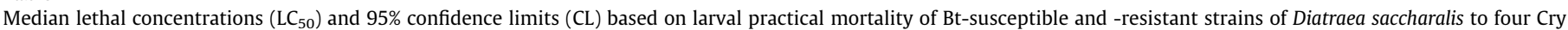
proteins. $^{\text {a }}$

\begin{tabular}{|c|c|c|c|c|c|c|c|}
\hline Cry protein & Insect strain & $n^{\mathrm{b}}$ & Slope \pm SE & $\mathrm{LC}_{50}(95 \% \mathrm{CL})(\mu \mathrm{g} / \mathrm{g})^{\mathrm{c}}$ & $\chi^{2}$ & df & Resistance ratio $^{d}$ \\
\hline \multirow[t]{8}{*}{ Cry1Ab } & Cry1Ab -SS & 503 & $3.41 \pm 0.36$ & $0.19(0.16,0.22)$ & 5.79 & 21 & - \\
\hline & Cry1Ab-RR-2004 & 723 & - & $>100$ & - & - & $>526$ \\
\hline & SCB-RR-43A & 568 & - & $>100$ & - & - & $>526$ \\
\hline & SCB-RR-L5B & 1365 & - & $>100$ & - & - & $>526$ \\
\hline & SCB-RR-L6 & 456 & $0.82 \pm 0.10$ & $24.57(14.70,51.10)$ & 16.17 & 22 & 129 \\
\hline & SCB-RR-41 & 376 & $1.17 \pm 0.17$ & $22.87(14.36,45.95)$ & 27.09 & 18 & 120 \\
\hline & SCB-RR-46 & 370 & $1.16 \pm 0.14$ & $22.11(15.27,36.59)$ & 18.13 & 18 & 116 \\
\hline & SCB-RR-54 & 574 & - & $>10$ & - & - & $>53$ \\
\hline \multirow[t]{8}{*}{ Cry1Aa } & Cry1Ab -SS & 317 & $2.73 \pm 0.37$ & $0.04(0.03,0.05)$ & 23.88 & 13 & - \\
\hline & Cry1Ab-RR-2004 & 364 & $1.90 \pm 0.17$ & $7.72(6.38,9.39)$ & 13.41 & 14 & 193 \\
\hline & SCB-RR-43A & 355 & $1.78 \pm 0.23$ & $11.68(8.48,17.15)$ & 30.80 & 18 & 292 \\
\hline & SCB-RR-L5B & 591 & $2.58 \pm 0.30$ & $4.11(3.27,5.15)$ & 89.00 & 30 & 103 \\
\hline & SCB-RR-L6 & 285 & $2.84 \pm 0.30$ & $6.33(5.24,7.73)$ & 16.39 & 18 & 158 \\
\hline & SCB-RR-41 & 348 & $2.50 \pm 0.33$ & $3.05(2.28,4.17)$ & 39.05 & 18 & 76 \\
\hline & SCB-RR-46 & 350 & $2.45 \pm 0.23$ & $3.76(3.15,4.50)$ & 13.23 & 18 & 94 \\
\hline & SCB-RR-54 & 612 & $1.87 \pm 0.75$ & $2.84(0.70,27.89)$ & 665.35 & 22 & 71 \\
\hline \multirow[t]{8}{*}{ Cry1Ac } & Cry1Ab -SS & 506 & $1.95 \pm 0.22$ & $0.23(0.17,0.32)$ & 46.30 & 18 & - \\
\hline & Cry1Ab-RR-2004 & 631 & $1.11 \pm 0.10$ & $61.41(46.06,88.01)$ & 14.30 & 18 & 267 \\
\hline & SCB-RR-43A & 652 & $1.99 \pm 0.17$ & $6.93(5.58,8.69)$ & 35.86 & 22 & 30 \\
\hline & SCB-RR-L5B & 805 & $0.97 \pm 0.08$ & $14.17(9.93,21.57)$ & 40.65 & 30 & 62 \\
\hline & SCB-RR-L6 & 245 & $1.65 \pm 0.45$ & $56.96(30.95,381.19)$ & 24.76 & 14 & 248 \\
\hline & SCB-RR-41 & 580 & $1.98 \pm 0.28$ & $9.49(6.49,14.06)$ & 96.56 & 22 & 41 \\
\hline & SCB-RR-46 & 267 & $0.84 \pm 0.13$ & $17.26(10.61,34.78)$ & 18.14 & 18 & 75 \\
\hline & SCB-RR-54 & 471 & $1.39 \pm 0.25$ & $8.81(5.62,15.44)$ & 57.35 & 14 & 38 \\
\hline \multirow[t]{8}{*}{ Cry1F } & Cry1Ab -SS & 540 & $1.60 \pm 0.11$ & $0.37(0.31,0.45)$ & 23.78 & 18 & - \\
\hline & Cry1Ab-RR-2004 & 735 & $1.07 \pm 0.08$ & $2.56(1.99,3.43)$ & 26.34 & 22 & 6.9 \\
\hline & SCB-RR-43A & 381 & $3.91 \pm 0.66$ & $0.57(0.44,0.74)$ & 46.00 & 18 & 1.5 \\
\hline & SCB-RR-L5B & 591 & $2.35 \pm 0.17$ & $1.83(1.58,2.13)$ & 25.40 & 18 & 4.9 \\
\hline & SCB-RR-L6 & 252 & $3.62 \pm 0.59$ & $1.94(1.49,2.55)$ & 29.13 & 14 & 5.2 \\
\hline & SCB-RR-41 & 645 & $1.59 \pm 0.14$ & $1.46(1.12,1.94)$ & 39.73 & 22 & 3.9 \\
\hline & SCB-RR-46 & 553 & $2.66 \pm 0.27$ & $0.88(0.72,1.08)$ & 33.07 & 18 & 2.4 \\
\hline & SCB-RR-54 & 623 & $1.83 \pm 0.22$ & $1.92(1.41,2.69)$ & 56.57 & 18 & 5.2 \\
\hline
\end{tabular}

\footnotetext{
a Practical larval mortality was defined as the number of dead larvae plus surviving larvae that did not demonstrate significant weight gains (<0.1 mg/larva) in a 7 -day bioassay divided by the total number of larvae in the test.

b $n=$ total number of neonates assayed.

c The $\mathrm{LC}_{50}$ value of an insect strain was considered to be greater than the highest Cry concentration used in the bioassay if its larval mortality was $<50 \%$ at the highest concentration.

${ }^{\mathrm{d}}$ Resistance ratios for a Cry protein were calculated by dividing the $\mathrm{LC}_{50}$ value of a Bt maize resistant strain by that of the Cry1 Ab-susceptible strain (Cry1 $\mathrm{Ab}$-SS).
} 
Cry 1 Ab-SS was $0.23 \mu \mathrm{g} / \mathrm{g}$ with a $95 \% \mathrm{CL}$ of $0.17-0.32 \mu \mathrm{g} / \mathrm{g}$ (Table 1 ). In contrast, the $\mathrm{LC}_{50}$ values for the seven resistant strains ranged from $6.93 \mu \mathrm{g} / \mathrm{g}$ for SCB-RR-43A (30-fold) to $61.4 \mu \mathrm{g} / \mathrm{g}$ (267-fold) for Cry1Ab-RR-2004. The differences between Cry1Ab-SS and the resistant strains were significant for all the seven resistant strains based on the non-overlapping of the 95\% confidence limits (Table 1). As observed in the bioassays with Cry1 Ab and Cry1 Aa, resistance ratios to Cry1Ac varied among the seven resistant strains. Except for SCB-RR-46 (75-fold), resistance ratios to Cry1Ac in Cry1 Ab-RR-2004 (267-fold) and SCB-RR-L6 (248-fold) were significantly greater than those observed in other strains (30- to 62-fold) based on the non-overlapping of the $95 \%$ confidence limits.

Compared to Cry1Ab, Cry1Aa, or Cry1Ac, all seven Cry1Ab maize-resistant strains of $D$. saccharalis showed considerably lower resistance ratios to Cry $1 \mathrm{~F}$. The calculated $\mathrm{LC}_{50}$ value of Cry $1 \mathrm{~F}$ for Cry $1 \mathrm{Ab}-\mathrm{SS}$ was $0.37 \mu \mathrm{g} / \mathrm{g}$ with a $95 \% \mathrm{CI}$ of $0.31-0.45 \mu \mathrm{g} / \mathrm{g}$ (Table 1 ). $\mathrm{LC}_{50} \mathrm{~S}$ of the seven resistant strains ranged from $0.57 \mu \mathrm{g} / \mathrm{g}$ for SCBRR-43A to $2.56 \mu \mathrm{g} / \mathrm{g}$ for Cry1Ab-RR-2004. The 1.5 -fold difference between Cry1Ab-SS and SCB-RR-43A was not significant based on the overlapping of the $95 \%$ confidence limits. The resistance ratios (2.4- to 6.9-fold) for the other six resistant strains were significant based on the non-overlapping of the $95 \%$ confidence limits. Varied susceptibility to Cry1F was also observed among the six resistant strains but the differences were small, <3-fold.

\subsection{Larval growth inhibition}

The main effect of insect strain and Cry concentration on larval growth inhibition was significant for all four Cry proteins $(F \geqslant 48.16 ; \quad \mathrm{df}=7,144-161 ; P<0.0001$ for insect strain and $F \geqslant 225.56 ; \mathrm{df}=5,144 ; P<0.0001$ for Cry concentration). The effect of the interaction of insect strain and Cry concentration was also significant $(F \geqslant 5.5 ; \mathrm{df}=33-35,144-161 ; P<0.0001)$. Larval growth inhibition of Cry1 Ab-SS and the seven Bt-resistant strains increased as Cry protein concentrations increased for all four Cry proteins (Fig. 1). However, except for Cry1F, growth inhibition of Cry1 Ab-SS strain increased considerably faster than that of the seven Bt-resistant strains.

The general patterns of concentration-larval growth responses were similar for Cry1Aa, Cry1Ab, and Cry1Ac (Fig. 1). At each Cry concentration, the effect of insect strain on larval growth inhibition was significant for all these three proteins $(F \geqslant 12.65$; $\mathrm{df}=7,28$; $P<0.0001$ for Cry1Aa, $F \geqslant 10.57$; $\mathrm{df}=6-7,24-28 ; P<0.0001$ for Cry $1 \mathrm{Ab}$, and $F \geqslant 4.58 ; \mathrm{df}=7,24-28 ; P \leqslant 0.0023$ for Cry1Ac). Larval growth of Cry1Ab-SS strain on diet treated with one of the three proteins was severely inhibited even at low concentrations. For example, at $0.1 \mu \mathrm{g} / \mathrm{g}$, Cry1 Aa, Cry $1 \mathrm{Ab}$ and Cry1Ac inhibited larval growth of the Cry $1 \mathrm{Ab}-\mathrm{SS}$ strain by $96.8 \%, 81.8 \%$ and $76.0 \%$, respectively, which were significantly greater $(P<0.05)$ than that observed for the seven resistant strains. Larval growth of Cry1 Ab-SS at $0.316 \mu \mathrm{g} / \mathrm{g}$ of Cry $1 \mathrm{Aa}, 3.16 \mu \mathrm{g} / \mathrm{g}$ of Cry $1 \mathrm{Ab}$, and $1 \mu \mathrm{g} / \mathrm{g}$ of Cry $1 \mathrm{Ac}$ was completely inhibited, while the corresponding growth inhibition was only $34.2-63.6 \%, 50.2-91.0 \%$, and $51.9-76.7 \%$, respectively, for the seven resistant strains. Larval growth of the seven resistant strains was not completely inhibited at 3.16 and $10 \mu \mathrm{g} /$ $\mathrm{g}$ for all three proteins but the growth was completely or nearly completely stopped at $31.6 \mu \mathrm{g} / \mathrm{g}$ for Cry1Aa and Cry1Ac. Differences in growth inhibition were also observed among the seven resistant strains. For Cry1Aa, growth inhibition of SCB-RR-43A, SCB-RR-L5B, and SCB-RR-41 at concentrations of $0.1-1 \mu \mathrm{g} / \mathrm{g}$ was generally greater than that of other resistant strains but the differences decreased or disappeared at $\geqslant 3.16 \mu \mathrm{g} / \mathrm{g}$. On Cry $1 \mathrm{Ab}$ treated diet, compared to other resistant strains, growth of Cry1Ab-RR2004 was less inhibited at most concentrations. In most cases,

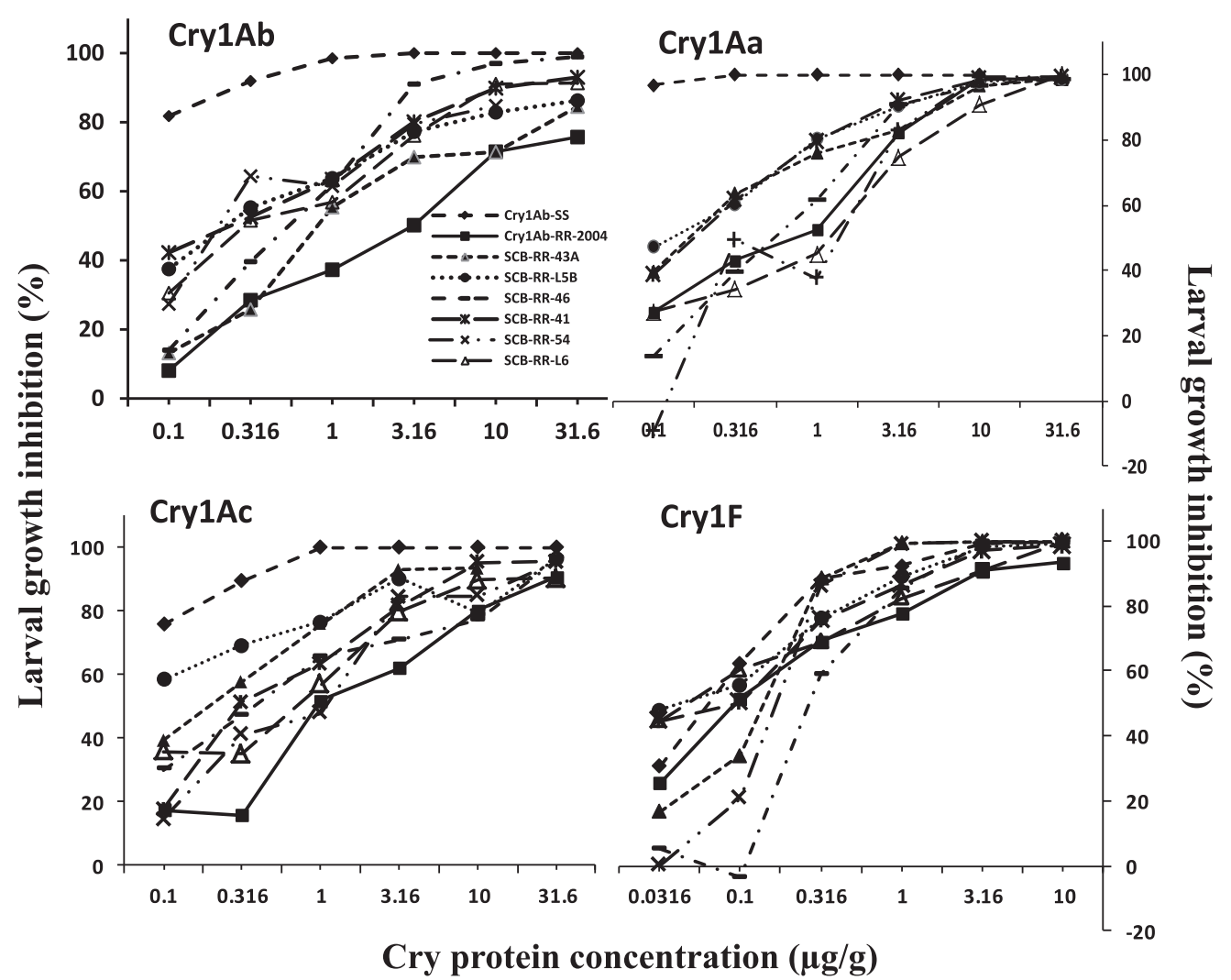

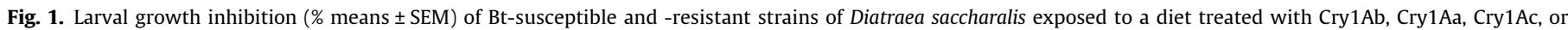

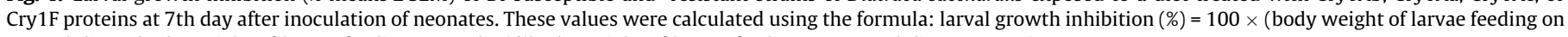
control diet - body weight of larvae feeding on Bt diet)/(body weight of larvae feeding on control diet $-0.1 \mathrm{mg}$ ). 
growth inhibition of SCB-RR-43A was also somewhat less than that of the other five resistant strains which showed similar dosegrowth response. For Cry1 Ac, relative to other resistant strains, larval growth of Cry1Ab-RR-2004 in most cases was also less affected at the concentrations of $0.1-3.16 \mu \mathrm{g} / \mathrm{g}$ but the differences became smaller at 10 and $31.6 \mu \mathrm{g} / \mathrm{g}$.

For Cry1F, effect of insect strain on larval growth inhibition of $D$. saccharalis was also significant at each of the six concentrations assayed $(F \geqslant 21.9 ; \mathrm{df}=7,24 ; P<0.0001)$. However, the difference among insect strains at a specific concentration was in general much smaller than that recorded in the bioassays with the other three Cry proteins. Unlike observed in the bioassays with Cry1Aa, Cry $1 \mathrm{Ab}$, or Cry1Ac, Cry1Ab-SS larvae did not show a consistently greater growth inhibition than the resistant strains at most concentrations tested. At 0.0316-0.316, growth inhibition of SCB-RR46 was significantly smaller than that observed in most other insect strains but the difference disappeared at $\geqslant 1 \mu \mathrm{g} / \mathrm{g}$.

\section{Discussion}

Because of the high cost to purchase purified Cry proteins, susceptibility of $D$. saccharalis to Cry $1 \mathrm{Ab}$ protein could be assayed up to only $100 \mu \mathrm{g} / \mathrm{g}$ in this study. The $\mathrm{LC}_{50}$ values could not be determined with the probit analysis for four of the seven resistant strains because larval mortality at the highest concentration tested did not reach $50 \%$ (Table 1 ). Nevertheless, the bioassay data showed that the Cry1Ab-SS strain was susceptible to Cry1 Ab protein with an $\mathrm{LC}_{50}$ value of $0.19 \mu \mathrm{g} / \mathrm{g}$, which was similar to the value reported in previous studies (Huang et al., 2007b, 2008). The known Cry1Ab-resistant strain (Cry1Ab-RR-2004) of D. saccharalis again exhibited highly resistant ( $>526$-fold) to Cry $1 \mathrm{Ab}$ in this study. The resistance levels of Cry1Ab-RR-2004 to Cry1Ab protein appeared to be greater than that observed in a bioassay that was conducted six years ago (Huang et al., 2007b). The Cry1Ab-RR2004 was continuously selected on Cry $1 \mathrm{Ab}$ maize leaf tissue since it was established in 2004-2005. The long-term continued selection apparently elevated the resistance ratio. The current study also demonstrated that all six strains of $D$. saccharalis that were collected in 2009 and identified to possess major resistance alleles to Cry $1 \mathrm{Ab}$ maize were also highly resistant to the purified trypsinactivated Cry $1 \mathrm{Ab}$ protein. Due to the availability of the amount of $\mathrm{Cry} 1 \mathrm{Ab}$ protein, the highest concentration used in assaying SCBRR-54 was only $10 \mu \mathrm{g} / \mathrm{g}$. At this concentration, larvae of SCB-RR54 showed only a very low mortality, $6.5 \%$, and thus the actual resistance ratio to Cry $1 \mathrm{Ab}$ in this strain should be much greater than 53-fold. Based on the larval growth data we expected that susceptibility of SCB-RR-54 to Cry $1 \mathrm{Ab}$ should be similar as observed in the other resistant strains. In summary, the results of this study provide clear evidence that the observed survival on Cry $1 \mathrm{Ab}$ maize in the $F_{2}$ screen in the six strains (Huang et al., 2012a) is the result of resistance to the Cry $1 \mathrm{Ab}$ protein in the plants.

Although all six strains of $D$. saccharalis that were established from field populations collected in 2009 were highly resistant to purified Cry1 Ab protein, variation in the Cry1 Ab susceptibility existed among strains. Based on larval growth and mortality, resistance level to Cry $1 \mathrm{Ab}$ in SCB-RR-43A and -L5B were apparently greater than in SCB-RR-L6, SCB-RR-41, and SCB-RR-46. The varied Cry1Ab susceptibility among these resistant strains warrants further study to find out the reasons that cause the differences. Different traits or mechanisms of resistance could exist among these strains. One of the advantages of $F_{2}$ screen is that it is able to detect different alleles of resistance in field populations (Andow and Alstad, 1998; Huang, 2006). However, the difference could be also due to varied levels of homozygosity of resistance among these strains because all of the six resistant strains had not been intensively selected after they were established using $F_{2}$ screen. The low slopes $(0.82-1.17)$ of the dose-response curves of the three strains that were available for probit analysis also indicate a non-homozygous status of the resistance alleles among individuals in these strains.

Cross-resistance is most likely when toxins share key structural features (Tabashnik et al., 1996). Data of this study showed that all seven Bt resistant strains of $D$. saccharalis demonstrated a significantly level of cross-resistance to Cry1Aa and Cry1Ac but the pattern of cross-resistance appears to be varied among insect strains and $\mathrm{Bt}$ proteins. Except for SCB-RR-L6, cross-resistance level to Cry1Aa appears to be positively correlated to the level of resistance to Cry1 Ab. In contrast, cross-resistance level to Cry1Ac was not highly correlated with the levels of Cry1 Ab resistance. For example, SCB-RR-43A was highly resistant to both Cry1Ab (>526-fold) and Cry1Aa (292-fold) but it showed the least cross-resistance level (30-fold) to Cry1Ac among the seven resistant strains, while SCBRR-L6 that showed a relatively low level (129-fold) of resistance to Cry $1 \mathrm{Ab}$ demonstrated a relatively high level of cross-resistance to both Cry1Aa (158-fold) and Cry1Ac (248-fold). The varied patterns of cross-resistance further indicate that different alleles and/or mechanisms of resistance could exist among these strains.

Varied cross resistance patterns for different Bt proteins have been reported in several other lepidopteran species targeted by Bt crops (Tabashnik et al., 1994; Ferré and Van Rie, 2002; Siqueria et al., 2004; Li et al., 2005; Pereira et al., 2010; Crespo et al., 2011). In most cases, the underlying physiological mechanisms of crossresistance among Bt proteins are complex and somewhat unpredictable (Bauer, 1995). It is believed that the most likely factor that relate to the cross-resistance patterns could be the specific binding sites in the insect midgut brush border membrane. In the diamondback moth, Plutella xylostella (L.), Granero et al. (1996) reported that Cry1 Ab and Cry1F shared a high-affinity binding site. Additional studies suggest that there may be four different Bt binding sites in the midgut of $P$. xylostella: site 1 for Cry1Aa; site 2 for Cry1Aa, Cry1Ab, Cry1Ac, Cry1F, and Cry1B; site 3 for Cry1J; and site 4 for Cry1C (Ballester et al., 1999; Ferré and Van Rie, 2002). Results of the present study showed that all seven Cry1 Ab resistant strains of $D$. saccharalis were also highly resistant to Cry1Aa and Cry1Ac, indicating these three Bt proteins could share similar binding sites, as suggested in P. xylostella. However, these highly Cry1Ab-resistant strains of $D$. saccharalis exhibited only a very low level (1.5to 6.9 -fold) of cross-resistance to Cry1F. The results of the present study support the assumption that, besides a low-affinity binding site shared for Cry1 Ab and Cry1F (Hua et al., 2001), there is another high-affinity binding site for Cry $1 \mathrm{~F}$ but not for Cry $1 \mathrm{Ab}$ in $D$. saccharalis as it is suggested in 0 . nubilalis (Siqueria et al., 2004; Crespo et al., 2011). Although considerable variation in cross-resistance to Cry1Aa, Cry1Ac, and Cry1F were observed among the seven Cry1Ab-resistant strains of $D$. saccharalis, the overall cross-resistance pattern to these Bt proteins in D. saccharalis is similar to that observed in 0 . nubilalis. Crespo et al. (2011) reported that a strain of 0 . nubilalis with $>1000$-fold resistance to Cry $1 \mathrm{Ab}$ also exhibited high levels ( $>535$-fold) of cross-resistance to Cry1Ac and Cry1Aa but only low levels ( $<4$-fold) of cross-resistance to Cry1F. Similar cross-resistance patterns were also observed in another strain of $O$. nubilalis that had a lower level of Cry1 Ab resistance (Siqueria et al., 2004). The low level of cross-resistance between Cry1A and Cry1F in the maize stalk borers suggests that pyramiding these two types of Cry proteins into a plant could be an effective strategy for managing maize stalk borers.

\section{Acknowledgments}

This article is published with the approval of the Director of the Louisiana Agricultural Experiment Station as manuscript No. 2012234-7574. This project represents work supported by the Louisiana 
Soybean and Feed Grain Promotion Board, USDA-AFRI South Regional IPM program, Monsanto Company, and USDA NC-205.

\section{References}

Abbott, W.S., 1925. A method of computing the effectiveness of an insecticide. J. Econ. Entomol. 18, 265-267.

Ali, M.I., Luttrell, R.G., 2007. Susceptibilities of bollworm and tobacco budworm (Lepidoptera: Noctuidae) to Cry2Ab2 insecticidal protein. J. Econ. Entomol. 100, 921-931.

Andow, D.A., Alstad, D.N., 1998. $F_{2}$ screen for rare resistance alleles. J. Econ. Entomol. 91, 572-578.

Ballester, V., Granero, F., Tabashnik, B.E., Malvar, T., Ferre, J., 1999. Integrative model for binding of Bacillus thuringiensis toxins in susceptible and resistant larvae of the diamondback moth (Plutella xylostella). Appl. Environ. Microbiol. 65, 14131419.

Bauer, L.S., 1995. Resistance: a threat to the insecticidal crystal proteins of Bacillus thuringiensis. Florida Entomol. 78, 414-443.

Cattaneo, M.G., Yafuso, C., Schmidt, C., Huang, C.Y., Rahman, M., Olson, C., EllersKirk, C., Orr, B.J., Marsh, S.E., Antilla, L., Dutilleul, P., Carrière, Y., 2006. Farmscale evaluation of the impacts of transgenic cotton on biodiversity, pesticide use, and yield. Proc. Natl. Acad. Sci. USA 103, 7571-7576.

Crespo, A.L.B., Rodrigo-Simón, A., Siqueira, H.A.A., Pereira, E.J.G., Ferré, J., Siegfried, B.D., 2011. Cross-resistance and mechanism of resistance to Cry1Ab toxin from Bacillus thuringiensis in a field-derived strain of European corn borer, Ostrinia nubilalis. J. Invertebr. Pathol. 107, 185-192.

Dhurua, S., Gujar, G.T., 2011. Field-evolved resistance to Bt toxin Cry1Ac in the pink bollworm, Pectinophora gossypiella (Saunders) (Lepidoptera: Gelechiidae) from India. Pest Manage. Sci. 67, 898-903.

Downes, S., Parker, T.L., Mahon, R.J., 2010. Characteristics of resistance to Bacillus thuringiensis toxin Cry2Ab in a strain of Helicoverpa punctigera (Lepidoptera: Noctuidae) isolated from a field population. J. Econ. Entomol. 103, 2147-2154.

Ferré, J., Van Rie, J., 2002. Biochemistry and genetics of insect resistance to Bacillus thuringiensis. Ann. Rev. Entomol. 47, 501-533.

Finney, D.J., 1971. Probit Analysis. Cambridge University Press, England.

Gassmann, A.J., Petzold-Maxwell, J.L., Keweshan, R.S., Dunbar, M.W., 2011. Fieldevolved resistance to Bt maize by western corn rootworm. PLoS ONE 6, e22629.

Ghimire, M.N., Huang, F., Leonard, B.R., Head, G.P., Yang, Y., 2011. Susceptibility of Cry1Ab-susceptible and -resistant sugarcane borer to transgenic corn plants containing single or pyramided Bacillus thuringiensis genes. Crop Protect. 30, 74-81.

Granero, F., Ballester, V., Ferre, J., 1996. Bacillus thuringiensis crystal proteins Cry1 Ab and Cry1Fa share a high affinity binding site in Plutella xylostella (L.). Biochem. Biophys. Res. Commun. 224, 779-783.

Hua, G., Masson, L., Jurat-Fuentes, J.L., Schwab, G., Adang, M.J., 2001. Binding analyses of Bacillus thuringiensis Cry delta-endotoxins using brush border membrane vesicles of Ostrinia nubilalis. Appl. Environ. Microbiol. 67, 872-879.

Huang, F., 2006. Detection and monitoring of insect resistance to transgenic Bt crops. Ins. Sci. 13, 73-84.

Huang, F., Leonard, B.R., Gable, R.H., 2006. Comparative susceptibility of European corn borer, southwestern corn borer, and sugarcane borer (Lepidoptera: Crambidae) to Cry1 Ab protein in a commercial Bt-corn hybrid. J. Econ. Entomol. 99, 194-202.

Huang, F., Leonard, B.R., Andow, D.A., 2007a. Sugarcane borer resistance to transgenic Bacillus thuringiensis-maize. J. Econ. Entomol. 100, 164-171.

Huang, F., Leonard, B.R., Wu, X., 2007b. Resistance of sugarcane borer to Bacillus thuringiensis Cry1Ab toxin. Entomol. Exp. Appl. 124, 117-123.

Huang, F., Leonard, B.R., Moore, S.H., Yue, B., Parker, R., Reagan, T., Stout, M., Cook, D.R., Akbar, W., Chilcutt, C., White, W., Lee, D., Biles, S., 2008. Geographical susceptibility of Louisiana and Texas populations of sugarcane borer, Diatraea saccharalis (F.) (Lepidoptera: Crambidae) to Bacillus thuringiensis Cry1 $\mathrm{Ab}$ protein. Crop Prot. 27, 799-806.

Huang, F., Ghimire, M.N., Leonard, B.R., Daves, C.D., Levy, R., Baldwin, J., 2012a. Extended monitoring of resistance to Bacillus thuringiensis Cry1 $\mathrm{Ab}$ maize in Diatraea saccharalis (Lepidoptera: Crambidae). GM Crop. Food: Biotech. Agric. Food Chain 3, 245-254.
Huang, F., Ghimire, M.N., Leonard, B.R., Zhu, Y.-C., Head, G., 2012b. Susceptibility of field populations of sugarcane borer from non-Bt and Bt maize plants to five individual cry toxins. Ins. Sci. 19, 570-578.

Hutchison, W.D., Burkness, E.C., Mitchell, P.D., Moon, R.D., Leslie, T.W., Fleischer, S.J., Abrahamson, M., Hamilton, K.L., Steffey, K.L., Gray, M.E., Hellmich, R.L., Kaster, L.V., Hunt, T.E., Wright, R.J., Pecinovsky, K., Rabaey, T.L., Flood, B.R., Raun, E.S., 2010. Areawide suppression of European corn borer with Bt maize reaps savings to non-Bt maize growers. Science 330, 222-225.

James, C., 2011. Global Status of Commercialized Biotech/GM crops. ISAAA Brief No.43. ISAAA: Ithaca, NY.

Li, H., Oppert, B., Higgins, R.A., Huang, F., Buschman, L.L., Zhu, K.Y., 2005. Susceptibility of Dipel-resistant and -susceptible Ostrinia nubilalis (Lepidoptera: Crambidae) to individual Bacillus thuringiensis protoxins. J. Econ. Entomol. 98, 1333-1340.

Mahon, R.J., Olsen, K.M., Garsia, K.A., Young, S.R., 2007. Resistance to Bacillus thuringiensis toxin Cry2Ab in a strain of Helicoverpa armigera (Lepidoptera: Noctuidae) in Australia. J. Econ. Entomol. 100, 894-902.

Masson, L., Erlandson, M., Pusztai-Carey, M., Brousseau, R., Juarez-Perez, V., Frutos, R., 1998. A holistic approach for determining the entomopathogenic potential of Bacillus thuringiensis strains. Appl. Environ. Microbiol. 64, 4782-4788.

Pereira, E.J.G., Siqueira, H.A.A., Zhuang, M., Stoner, N.P., Siegfried, B.D., 2010. Measurements of Cry1F binding and activity of luminal gut proteases in susceptible and Cry1F resistant Ostrinia nubilalis larvae (Lepidoptera: Crambidae). J. Invertebr. Pathol. 103, 1-7.

PRNewswire, 2009. Dow AgroSciences receives approval for cultivation of Herculex ${ }^{\circledR} I$ corn in Brazil. <http://www.prnewswire.com/news-releases/dowagrosciences-receives-approval-for-cultivation-of-herculexr-i-corn-in-brazil61249277.html> (29.04.12).

Pusztai-Carey, M., Carey, P., Lessard, T., Yaguchi, M., 1995. Isolation, quantification and purification of insecticidal proteins from endotoxins of Bacillus thuringiensis. US Patent No.5356788.

SAS Institute Inc, 2010. SAS/STAT: 9.3 User's Third Edition SAS Institute Inc, Cary, NC.

Siqueria, H.A.A., Moellenbeck, D.J., Spencer, T.A., Siegfried, B.D., 2004. Crossresistance of Cry1 Ab-selected Ostrinia nubilalis (Lepidoptera: Crambidae) to Bacillus thuringiensis $\delta$-endotoxins. J. Econ. Entomol. 97, 1049-1057.

Storer, N.P., Babcock, J.M., Schlenz, M., Meade, T., Thompson, G.D., Bing, J.W., Huckaba, R.M., 2010. Discovery and characterization of field resistance to Bt maize: Spodoptera frugiperda (Lepidoptera: Noctuidae) in Puerto Rico. J. Econ. Entomol. 103, 1031-1038.

Tabashnik, B.E., Finson, N., Johnson, M.W., Heckel, D.G., 1994. Cross-resistance to Bacillus thuringiensis toxin CryIF in the diamondback moth. Appl. Environ. Microbiol. 60, 4627-4629.

Tabashnik, B.E., Malvar, T., Liu, Y.B., Finson, N., Borthakur, D., Shin, B.S., Park, S.H., Masson, L., Maagd, R.A., Bosch, D., 1996. Cross-resistance of the diamondback moth indicates altered interactions with domain II of Bacillus thuringiensis toxins. Appl. Environ. Microbiol. 62, 2839-2844.

Tabashnik, B.E., Liu, Y.B., De Maagd, R.A., Dennehy, T.J., 2000. Cross-resistance of pink bollworm (Pectiniphora gossypiella) to Bacillus thuringiensis toxins. Appl. Environ. Microbiol. 66, 4582-4584.

Van Rensburg, J.B.J., 2007. First report of field resistance by the stem borer, Busseola fusca (Fuller) to Bt-transgenic maize. S. Afr. J. Plant Soil. 24, 147-151.

Wangila, D.S., Leonard, B.R., Bai, Y., Head, G.H., Huang, F., 2012. Larval survival and plant Injury of Cry1Ab-susceptible, -resistant, and -heterozygous genotypes of the sugarcane borer on transgenic corn containing single or pyramided Bt genes. Crop Prot. 42, 108-115.

Wu, X., Huang, F., Leonard, B.R., Moore, S.H., 2007. Evaluation of transgenic Bacillus thuringiensis corn hybrids against Cry1 Ab-susceptible and -resistant sugarcane borer (Lepidoptera: Crambidae). J. Econ. Entomol. 100, 1880-1886.

Wu, K.M., Lu, Y.H., Feng, H.Q., Jiang, Y.Y., Zhao, J.Z., 2008. Suppression of cotton bollworm in multiple crops in China in areas with Bt toxin-containing cotton. Science 321, 1676-1678.

Wu, X., Leonard, B.R., Zhu, Y.C., Abel, C.A., Head, G.P., Huang, F., 2009. Susceptibility of Cry1 Ab-resistant and -susceptible sugarcane borer (Lepidoptera: Crambidae) to four Bacillus thuringiensis toxins. J. Invertbr. Pathol. 100, 29-34.

Zhao, J.Z., Li, Y.X., Collins, H.L., Cao, J., Earle, E.D., Shelton, A.M., 2001. Different crossresistance patterns in the diamondback moth (Lepidoptera: Plutellidae) resistance to Bacillus thuringiensis toxin Cry1AC. J. Econ. Entomol. 94, 15471552. 